\title{
Sand size versus beachface slope - An explanation based on the Constructal Law
}

\author{
A. Heitor Reis ${ }^{a, *}$, Cristina Gama ${ }^{b}$ \\ a Department of Physics and Geophysics Centre of Evora, University of Évora, R. Romão Ramalho 59, 7000-671 Evora, Portugal \\ ${ }^{\mathrm{b}}$ Department of Geosciences and Geophysics Centre of Evora, University of Évora, R. Romão Ramalho 59, 7000-671 Evora, Portugal
}

\section{A R T I C L E I N F O}

\section{Article history:}

Received 19 February 2009

Received in revised 21 July 2009

Accepted 24 July 2009

Available online 3 August 2009

\section{Keywords:}

Beachface dynamics

Sediment size

Beach slope

Constructal Law

\begin{abstract}
A B S T R A C T
The relationship between beachface slope and sand grain size has been established based on multiple observations of beach characteristics in many parts of the world. We show that this observational result may be understood in the light of the Constructal Law (Bejan, 1997). A model of wave run-up and run-down along the beachface (swash) was developed to account for superficial flows together with flows through the porous sand bed of average porosity 0.35 , the permeability of which may be related to grain diameter and sphericity ( 0.9 for sand grains) through the Kozeny-Carmán equation. Then, by using the Constructal Law, we minimized the time for completing a swash cycle, under fixed wave height and sand grain diameter. As the result, a relationship involving sand grain size, beachface slope and open ocean wave height has been obtained, and then discussed and validated against experimental data. In addition, this relationship has also been used to illuminate beachface dynamic processes, namely the reshaping of sandy beachfaces in response to changes in wave height. Though the model used in this work may be improved further, the results appear to show, as with other natural systems, that beachface morphing in time may be understood based on a unifying principle - the Constructal Law.
\end{abstract}

(c) 2009 Elsevier B.V. All rights reserved.

\section{Introduction}

The beachface is the sub-aerial beach sector, below the berm, that presents the steepest slope. This sector is exposed to wave swash that is responsible for sediment transport. Beachface gradient in relation to sediment transport and beach profile evolution has been studied from different perspectives: (i) by considering the beachface sediment characteristics, sediment grain size and sorting (Bagnold, 1940; Bascom, 1951; Wiegel, 1964; Turner, 1995; Wilson et al., 2008); (ii) or by accounting for swash infiltration/exfiltration effects on the equilibrium beachface profile in the cross-shore sediment transport (Grant, 1948; Kemp, 1975; Quick, 1991; Turner, 1995; Hughes et al., 1997; Masselink and Hughes, 1998; Turner and Masselink, 1998; Butt and Russell, 1999; Hughes and Turner, 1999; Puleo et al., 2000; Butt et al., 2001; Masselink and Li, 2001; Baldock and Hughes, 2006; Masselink and Puleo, 2006); and (iii) beach groundwater flow in the swash zone (Hegge and Masselink, 1991; Turner, 1993; Kang and Nielsen, 1996; Turner, 1998; Nielsen, 1999; Li et al., 2002; Horn, 2006).

The relationship between beach grain size and beach states ranging from those with steep reflective slopes to those with shallow, dissipative slopes has been examined by Wright and Short (1984) in terms of the dimensionless sediment fall velocity parameter, $\Omega=H_{\mathrm{b}} / W_{\mathrm{s}} T$, where $H_{\mathrm{b}}=$ breaker height; $W_{\mathrm{s}}=$ sediment fall

\footnotetext{
* Corresponding author. Tel.: +351 967324948; fax: +351 266745394.

E-mail address: ahr@uevora.pt (A.H. Reis).
}

velocity and $T=$ wave period (Gourlay, 1968). The sediment fall velocity parameter has been judged as a rather crude estimator of beach morphodynamic states (e.g. Anthony, 1998; Levoy et al., 2000; Masselink and Pattiaratchi, 2001; Jackson et al., 2005), and may, therefore, be considered as inadequate in reliably characterising beachface types within the reflective-dissipative beach continuum. Anthony (1998) has suggested that beach parameters based on slope, such as the Iribarren number (see Section 2), are better indicators of beach morphodynamic type than sediment size.

The proportionality between beachface gradient and sediment size was described by several authors (e.g. Bascom, 1951; McLean and Kirk, 1969; Dubois, 1982; Sunamura, 1984; Komar, 1998) who related this aspect to swash infiltration and hydraulic conductivity (permeability). If swash infiltration is significant, the water that infiltrates will not participate in the backswash (Kemp, 1975), and this controls beachface slope in relatively coarse sand beds (Bagnold, 1940; Quick, 1991). Swash infiltration depends on the permeability of the sediments bed which increases with grain size and sorting (Bascom, 1951; Shepard, 1963; Pryor, 1973; Selley, 1988; Masselink and Li, 2001). In coarse sand beaches (>1 mm) where swash infiltration is very important the beachface slope tends to increase with permeability (Quick, 1991; Komar, 1998; Masselink and Li, 2001).

With respect to importance of infiltration and exfiltration in the swash zone sediment transport and beach profile evolution, Butt et al. (2001) suggested that in coarse sand beds onshore sediment transport due to the effects of swash infiltration/exfiltration becomes important. These authors pointed out that a critical grain size might 